\title{
Anti-legal Ideology of Extremism
}

\author{
Nozim Abdullaev*, \\ Faculty of Law, Russian-Tajik Slavonic University, 30 M. Tursunzoda St., Dushanbe, 734025, Tajikistan
}

\begin{abstract}
The paper considers the extremist ideology as anti-legal activity and presents the study of scientific views on ideology as an element of extremist activity. The Article 30 of the Constitution of the Republic of Tajikistan prohibits any campaigning and propaganda provoking social, national, racial, religious hostility and hatred. The problem of criminal law standards on extremist activity includes lack of uniform approaches to extremism ideology in the Republic of Tajikistan and regarding some issues of applying such standards. In practice, this raises questions concerning differentiation of ideology, which makes it difficult to qualify extremist crimes. The analysis of anti-extremism legislation of the Republic of Tajikistan revealed some disadvantages and the authors proposed to introduce certain changes and amendments to close the gaps in the legislation in this respect.
\end{abstract}

\section{Introduction}

The subject presents a particular interest since the modern society of the Republic of Tajikistan is characterized by considerable prevalence of extremist ideology representing public danger as it is the extreme form of action appealing for destabilization of society, change of foundations of the constitutional system in the country, as well as racial, national, social and religious agitation. By denying the main constitutional rights and freedoms of citizens or opposing the existing structure of power relations, the extremism represents socially dangerous phenomenon.

The Shanghai convention on combatting terrorism, separatism and extremism of 15 June 2001 defines 'extremism' as follows (Item 3, Section 1, Article 1): "extremism - any act aimed to violent upheaval or violent retention of power, as well as violent change of the state constitutional system, and equally violent infringement of public safety, including organization within the above purposes of illegal armed groups or participation in them, which are criminally prosecuted according to the national legislation of the parties" [1].

This Shanghai convention was signed by Kazakhstan, the People's Republic of China, the Kyrgyz Republic, the Russian Federation, the Republic of Tajikistan and Uzbekistan.

Based on the division of individuals according to their specified status (ethnic, racial or other), extremism leads to dissociation, failure of social relations and, as a result, to disorganization and split of society.

The degree of its danger increases repeatedly in modern multinational world when intensive processes of migration, development of communication means and mass media result in ever complicated internal diversity of societies.
This phenomenon contributed to the adoption of the National Strategy on Combatting Extremism and Terrorism for 2016-2020 in the Republic of Tajikistan [2].

One of the main objectives of this strategy is to consolidate efforts of public authorities, local governments in settlements and villages, civic institutions and international organizations in order to suppress the distribution of extremist and terrorist ideas and activity. All this is promoted by the basic element of extremist activity, namely the extremist ideology. It serves the tool of influencing people thus winning them over.

\subsection{Problem Statement}

The 'ideology of extremism (extremist ideology)' is a system of thoughts and ideas representing violent and other illegal acts as the main means to resolve social, race, national, religious and political conflicts [3].

The extremist ideology promotes extremist activity and serves the basis to consolidate the activity of extremists and their organizations. To define the principles of extremist ideology it is insufficient to highlight some ideas, which may be presented as common features and characteristics of extremism, while many authors are quite often limited by this approach. Such ideas as the idea of social, racial, national inequality are usually suggested to characterize extremism.

The modern scientific literature defines extremism in its enlarged sense as the ideology ensuring the following:

- involuntary dissemination of its principles;

- intolerance to opponents, rejection of dissent;

Corresponding author: n.abdullaev.88@mail.ru 
- attempts of ideological justification of violence towards any persons not sharing the beliefs of extremists;

- appeal to any religious or ideological doctrines with claims for their genuine interpretation and at the same time substantial denial of many provisions of this interpretation;

- dominance of emotional pressure on consciousness of people in the course of extremism ideology propaganda, appeal to feelings of people but not to their minds;

- creation of a charismatic image of the leader of extremist movement, strive to present him as an infallible figure.

\section{Results and Discussion}

\subsection{Ideologization of extremist activity}

Extremist attitudes, beliefs, ideas and views are spread within a society more widely than open aggression and hatred, and are present in its all sectors. Such 'unrefined' extremism being 'dissolved' into public consciousness fosters basis social tensions. Of no less importance is the fact that by forming the daily background for regular activity of individuals the latent extremism exerts impact on socialization and attitude of the younger generation thus replicating in future generations. All these features are interrelated and complementary.

Extreme ideologization of extremist activity promotes the special type of extremists receptive to selfexcitation and loss of control over behavior and committed acts, ready for any action.

The supporters of extremist ideology may be so obsessed with their rightness and legitimacy of requirements that voluntarily or not they adjust the variety of life situations and processes to the world vision through the lens of this ideology. Historical cases of achieving the goals by unpopular measures allow extremism leaders to create similar cases hoping that the history will justify them.

The extremist ideology may anticipate the belief in the 'highest knowledge', which may only be gained by the 'elite', while for the 'ordinary' people it is assumed 'incomprehensible'. This criterion forms the basis for social (class) structure of society distinguishing the political elite.

Quite often the extremist ideology comprises methods of total public management in order to direct its development towards simingly 'necessary' and 'correct' future. At the same time such development of a society is understood as 'genuine' and 'logically obvious' with complete negation of other options.

The urge to unambiguously predict future development of society based on interpretation of its historical stages in order to justify the 'inevitable' and 'lawful' revolution or war is typical for extremist ideology. Despite the fact that historical events are often distorted and interpreted restrictively by ideologists out of touch with their historical context, objectives and tasks typical for certain stages of public development, the 'fidelity' of political doctrine is presented to the public as an indisputable fact and acts as a powerful ideological weapon in the hands of extremists [4].

This feature of extremist ideology may also be presented slightly differently as the so-called 'deterministic image of history'. Such image is based on historicism that is why the opinion, according to which historical development of reality definitely makes sense and purpose, is shared by extremists as compelling grounds. Supporters of such views try to identify the historical mechanism of such development and, thereby, to predict its future in order to justify their current and subsequent political actions.

The extremist ideology also refers to ideology proclaiming political homogeneity and social collectivism, i.e. when the value of a group, a team or a state is placed ahead of rights and interests of a certain person. In this respect a person isolated from any team or a certain group has neither recognition nor value. Such ideology neglects pluralism as a condition of open society and advocates political unity of the ruling and the dependent.

The idea forms the key aspect of extremist activity since it is manifested in the following actions:

a) dismantlement of constitutional system and violation of integrity of the Republic of Tajikistan;

b) erosion of safety of the Republic of Tajikistan;

c) seizure or assumption of power;

d) creation of illegal armed groups;

e) terrorist activity;

e) incitement of racial, national or religious discord, as well as social discord bound to violence or calls for violence;

g) violation of national dignity;

h) mass riots, rages and acts of vandalism based on ideological, political, racial, national or religious hatred or hostility similar to hatred or hostility towards any social group;

i) propaganda of exclusiveness, superiority or inferiority of citizens based on their attitude to religion, social, racial, national, religious or language identity;

j) public calls for the specified activity or commission of specified actions;

k) funding for specified activity or other assistance to implementation or commission of the specified actions by granting real estate, educational, printing and material resources, telephone, facsimile and other types of communication, information services, other facilities [5].

\subsection{Features of extremist activity}

The literature traditionally determines extremism with the focus on characteristic of extremist activity where the attention is paid to the main types of extremist actions. However, motives of such actions are either not revealed at all or described in a relatively abstract and vague manner. It seems that when determining the extremist activity it is not only critical to list kinds of specific actions of extremists but to indicate their ideological grounds. Only the activity, which is caused and 
motivated by extremist ideology, is considered extremist [6].

All scientists studying the extremist activity share the common opinion that extremist ideology forms the basis for extremist activity.

Sergun E.P. writes that "the basis of extremist motive of crime is always formed by the commitment to extremist ideology and not to any other ... For example, the authors believe that ideological hatred of national socialism is not extremism, and the crime committed for such motive towards representatives of the corresponding political movements and public associations functioning in modern society shall be subject to criminal qualification upon common grounds. However, proceeding from the current edition of item "e", Section 1, Article 63 of the Criminal Code of the Russian Federation, the hatred of national socialism or fascism may be considered as 'ideological hostility', therefore the legal literature reasonably poses a question on "what does in general the considered law protect against?" [7].

As M.Ya. Yakhyaev notes: "The extremist mental pattern of personality evolves from extremist ideology implying the inflated and destructive change program of a social environment or a situation when this ideology becomes a key aspect of personality orientation and defines its emotional and coping behavior".

The ideology may be called the system of worldviews realizing and estimating the attitude of people towards social reality. The subject of beliefs and extremist personality orientation may not be based on any ideology but only on ideology, which is defined as extremist. Specific extremist ideology is a primary element and a key prerequisite of extremism, its core as a special condition of mentality" [8].

B.B. Bidova identifies the following characteristics of extremist ideology:

1) idea of exclusive validity of this ideology, the socalled 'complex of absolute validity';

2) idea of aggressive intolerance towards all ideological competitors or competing alternative ideologies;

3) division of mankind into two large groups: insiders and outsiders, friends and enemies (whatever principle such division is based on it always characterizes human ideology);

4) focus on immediate practical activities aimed to change the world and people (program of immediate and resolute transformation of the existing social reality);

5) prevalence of destructive tasks aimed to destroy false hostile world over constructive tasks within the program of transformational actions;

6) fantastic, almost impossible, too severe and sophisticated code of personal behavior demanding some outstanding and extraordinary acts and victims [9].

The explanatory dictionary under the editorship of D.N. Ushakov defines the concept of ideology as a worldview, a system of thoughts and ideas [10].

Some dictionaries contain a more complete definition: ideology is the system of thoughts and ideas characterizing any social group, class, political party, society [11]. According to this definition the ideology may typify a large or small social group, society in general, certain community of people, but not an individual.

The domestic science describes several approaches to extremism ideology. Thus, for example, V.S. Martyanov denies any ideology of extremist activity considering that "there is no and cannot be separately existing extremist thinking and even extremist ideology" [12].

Z.S. Arukhov simply reduces this ideology to various manifestations of extremism claiming that "extremists try to call for any ideological or religious doctrines, try to justify their activity through emotional influence while promoting their extremist ideas and appealing to feelings and prejudices of people but not to their minds" [13].

A famous researcher of criminal extremism V.A. Burkovskaya believes that the "ideology becomes extremism if it bears the following features: 1) 'unambiguous' explanation of global problems and suggestion of similar 'easy and definitely beneficial' ways to solve them; 2) division of life into 'universal good or evil', where the evil covers almost everything that does not fit into this system; 3 ) exaggeration of one problem making it dominant and inappropriate for public hierarchy of values; 4) disregard and leveling of other values and norms" [14].

In literature it is noted that the "ideology is not a separate view or idea, but the system of the latter ones typical not for one individual but for a certain community of people" [15].

It seems that the inclusion of ideological motive into the list of extremist motives leads to unreasonable expansion of extremist crimes.

\section{Conclusion}

In summary, all scientists studying the extremist activity share the common opinion that the extremist activity is based on extremist ideology, which is understood as a set of ideas related to social, racial or national inequality, as well as extremist activity aimed to mobilize people for such activity.

Due to the aforesaid it is believed that the motive of ideological hatred and hostility shall be understood in its narrow context being only limited to hatred and hostility towards extremist ideology.

The authors prefer to avoid the notion of 'radical ideology' since they believe that unlike concepts characterizing either part of ideological pattern such as 'socialism', the notion of 'radicalism' is merely situational.

The anti-legal ideology of extremism is primarily focused on the destruction of civil society and sovereignty of the state thereby leading to violation of constitutional rights and freedoms of people and citizens and promoting tensions among various social groups.

In other words, the anti-legal ideology of extremism is the reason of excitement of national, racial, religious discord or hostility. Besides, the idea of aggressive intolerance and denial of tolerant attitude existing in modern society are able to undermine the public 
principles. Therefore, it is critical to introduce certain clarity to definitions followed by further changes and amendments in order to close the gaps in anti-extremism legislation.

\section{Acknowledgment}

The author expresses his gratitude to the Russian-Tajik Slavonic University for financing the research under the University Development Program for 2018.

\section{References}

1. Shanghai convention on combatting terrorism, separatism and extremism, Retrieved from: http://base.garant.ru/2561763/

2. National strategy of the Republic of Tajikistan No. 776 on combatting extremism and terrorism for 2016-2020 of 12 November 2016, Retrieved from: http://www.adlia.tj/show_doc.fwx? rgn=128036

3. S.I. Ozhegov, N.Yu. Shvedova, Explanatory dictionary of the Russian language. (Moscow, 2008)

4. M.Ya. Yakhjyaev, Origin and reasons of extremism as a negative social phenomenon. Extremism phenomenon: methodological problems of study, Scientific bulletin of Volgograd Academy of Public Administration, Political science and sociology, 1 (5), (2011)

5. Law of the Republic of Tajikistan "On combatting extremism" (Akhbori Majlisi Oli of the Republic of Tajikistan, 2003, No. 12, Art. 697; 2007, No. 3, Art. 158; Law RT No. 1146 of 27.11.2014) Retrieved from: http://www.mmk.tj/ru/view_sanadhoview.php?show detail $=\&$ sanadID $=1$

6. B.B. Bidova, Psychological and political understanding of extremism. Young scientist, 1 (2013)

7. V.S. Martyanov, Evil multiplication by good. Free thought, 5, 83 (2008)

8. M.Ya. Yakhjyaev, Extremism as a special condition of mentality, Collection: State and law: theory and practice. Proceedings of the II International scientific conference, 93-96 (2013)

9. B.B. Bidova, Psychological and political understanding of extremism, Young scientist, 1, 259-260 (2013)

10. D.N. Ushakov, Explanatory dictionary of modern Russian language, (Moscow, 1938)

11. E.E. Ganayeva, Youth extremism as a deviation type, Young scientist, 12, 361-363 (2012)

12. V.S. Martyanov, Evil multiplication by good, Free thought, 5, 85 (2008)

13. Z.S. Arukhov, Extremism in modern Islam. (Makhachkala, 1999)

14. A.S. Grachev, Political extremism, (Moscow, 1986)

15. V.A. Burkovskaya, Criminal religious extremism in modern Russia, 13-15 (2005)

16. S.V. Borisov, A.V. Zherebchenko, Qualification of extremist crimes. (Study guide, 2011)

17. Constitution of the Republic of Tajikistan (adopted on 6 November 1994; amended and revised on 26 September 1999, 22 June 2003 and 22 May 2016). Retrieved from: http://www.mmk.tj/ru/ 